\title{
EFFECT OF PLANT GEL ON THE FLOWERS OF BALCONIES GARDEN (Verbena canadiensis) UNDER SULAYMANI CITY CONDITIONS
}

\author{
ALI O. M. SHARBAZHERY and LAVA ANWAR ABU-BAKR \\ Dept. of Horticulture, Faculty of Agriculture, University of Sulaymani, Kurdistan Region-Iraq. \\ Agricultural Research Center-Sulaymani, Kurdistan Region-Iraq.
}

(Received: November 26, 2015; Accepted for publication: October 9, 2017)

\begin{abstract}
The experiment was carried out at the Agricultural Research Center - Bkrajo - Sulaymani City , in one Balconies with the direction to the south-west, at an altitude of $738 \mathrm{~m}$, during the period between May $\mathbf{1}^{\text {st }}$, 2012 to December $15^{\text {th }}, 2012$, to study the effects of plant Gel added to balcony's potting plants media under the environmental conditions of the Sulaymani city, with four level $0,30,75$ and $100 \mathrm{gm} \mathrm{Gel} /$ pot. The experiment was laid out in a complete randomized design (CRD) with four replicates.

The study results showed that the $100 \mathrm{gm}$ Gel treatment on the reduced significant irrigation requirements by $20.3 \%$, the rate of increase in soil moisture reaches to $74.9 \%$ compared with control , also increase significantly each of the Plant branches numbers and floral clusters numbers that 250 and $251.8 \%$ respectively when compared with control, As well as increased each of the Plant fresh, foliage dry weight at high rates for each of them, also increasing the flowering period by $169.1 \%$.
\end{abstract}

KEYWORDS : Apartment balcony's plants, Plant Gel, Verbena Canadensis .

\section{INTRODUCTION}

B alcony gardens is a type of private garden that fits apartments in residential buildings, in those places we can grow climbing plants or flowering plants in containers, boxes and hanging baskets (Flink and Searns, 1993).

Although putting plants in balconies under the environmental conditions of the Sulaymani city , especially during the hot days in the summer and autumn which needs to make the irrigation process several times in one day, an important strategy for reducing these needs is to improve the amount of available water for plant growth in the medium , otherwise leads to death or loss of plants aesthetic

This should be considered in finding materials or media keeps the water and soil moisture for a long time to reduce water requirements. This material may be polymers or plant gel, its small, clear, hard crystals, made of a water-absorbing polymer, all the polymers, Polyacrylamide is one of the most widely employed soil conditioners, this product has been determined to be nonhazardous, Contents; 94\% co-polymer of polyacrylamide (cross-linked); 5-6\% moisture. superior absorption rates 400 times its density in de-ionized water, when added to soil media, provide reserve water for plants, stored in hydrated crystals the additional water is stored bin crystals, 95\% available to plants for use, improves soil conditions (Zhang et al., 2006; Zohuriaan and Kabiri, 2008; Jatav et al., 2013), this leads to a reduce in watering frequency - by $50-75 \%$ in potted plants, by $15-40 \%$ on lawns and $20-40 \%$ on irrigated field crops. Gel reduces leaching fertilizers, stores and releases soluble fertilizer and nutrients, good for hanging baskets, stops them from drying out (Jatav et al., 2013). Also Bowman et al (1990) explained that adding Gel would improve the moisture-holding capacity of most container's media. Jamalpour et al (2013) also noted that the use of $15 \mathrm{~g}$ superabsorbent polymer per $1 \mathrm{~kg}$ soil can be offered with $10-12$ days irrigation period for Lysimachia nummularia cv. 'Aurea'. Moreover reduce the rate of water loss by evaporation and drainage, enabling you to water less. Another excellent benefit of these products is that once applied, they can continue to work from 5 to 7 years with just one treatment (El-Hady et al. 1981; Pill and Jacono 1984; Baker 1991).

Applications for potted plants when possible can mix crystals with fresh potting soil and repot 
plants, use dry granules or 2 cups of hydrated gel for $20 \mathrm{~cm}$ pot dry granules or 6 cups of hydrated gel for $25 \mathrm{~cm}$ pot (Wang and Gregg, 1990).

The goal of this study was to evaluate the effects of plant gel on balcony's potting plants under the environmental conditions of the Sulaymani city.

\section{MATERIALS AND METHODS}

The experiment was carried out at the Agricultural Research Center - Bkrajo , in one Balconies with the direction to the south-west, at an altitude of $738 \mathrm{~m}$ above the sea level, during the period between May 1st to December 15th, 2012 , plastic pots of $30 \mathrm{~cm}$ diameter and $40 \mathrm{~cm}$ height were used, the experiment consisted of four treatment $0,30,75$ and $100 \mathrm{gm} \mathrm{Gel}(\mathrm{Gel}$ was a German Origin), by four replications. To create a mixture of growing media which was consisted of agricultural soil, sandy loam and peat moss with proportions of 1: 1: 1, then put media inside the pots after mixing with the Gel. Pots were planted by one seedling of Verbena, Verbena canadiensis 'Homestead Purple' is perennials, groundcovers with bright purple flowers produced on short spikes in along summer, it grows about $30 \mathrm{~cm}$ height and $40 \mathrm{~cm}$ diameter (Burrell, 1999). Then pots were put in the balcony so that all the plants were displayed to the same site conditions. From the first day of experiment, some data measurements were begun to be taken, including the following experimental data:

1- Irrigation water requirements: The average of irrigation water was calculated daily for each treatment, according to the needs of each plant (pot), since interruption rain (May 29, 2012) until autumn rainfall (November 1).

2- Soil $\mathrm{pH}$ : was measured by using $\mathrm{pH}$ Meter .

3- Soil moisture: Was measured by using Digital Tension Meter.

4- Plant fresh weight and roots fresh weight (g): At the end of the experiment, plants were uprooted in pots and washed with water after drying for taking required measurements.

5- Flowering period: It was calculated that the average number of flowering days for each treatment from the beginning of the opening of the first flower in the cluster until the end of the plants flowering.

6- Branches numbers and floral clusters numbers: Most of the plant branches ending configure a cluster of flowers.
7- Plant length $(\mathrm{cm})$ : Plants were measured at the end of the growing season (December 15).

8- Foliage dry weight: It was calculated at the end of the experiment, dry weight was measured after drying the vegetative part in the oven at a temperature of $70{ }^{\circ} \mathrm{C}$ for 48 hours.

The experiment was laid out in a complete randomized design (CRD) with four replicates, the means were compared by use LSD test at the level of $5 \%$.

\section{RESULTS AND DISCUSSION}

1- Irrigation water requirements and soil moisture: The results of statistical analysis presented in table ( 1 ) indicated a clear high impact to the sum of Plant Gel to the soil, that significantly reduced the amount of irrigation water, and the best result was in the treatment of 100 gm Gel, which obtained 51 liters compared with control which need 64 liters, with reducing percent reaches to $20.3 \%$, as well as each of the two treatments 75 and $30 \mathrm{~g}$ significantly reducing the rate of irrigation water which was decreased to 12.5 and $4.7 \%$ respectively. Also led to a significant increase in the percentage of moisture of soil for the three treatments by 20.60, 20.45 and $22.30 \%$. compared with the Control (12.75), and soil moisture in the treatment of $100 \mathrm{gm} \mathrm{Gel}$ increased to $74.9 \%$ compared to the Control.

The reason for these effects may be due to the effect of Gel in its high ability to store water 200 - 400 times its size and keeps them around the roots of plants, and slowly releases it into the root zone to be used by plant roots, significantly increases the water-holding capacity of soil and can prevent plant loss due to drought stress in nonirrigated areas and where water-holding capacity is low (Gehring and Lewis, 1980; Taylor and Halfacre, 1986; Bowman et al., 1990; Zhang et al., 2006; Bai et al., 2010 and Jamalpour et al., 2013).

2- Soil pH: Notes from the results of table ( 1 ) shows there are no significant difference among treatments and control, with $\mathrm{pH}$ values higher or lower, so the experiment results show that the Gel has less impact than the soil $\mathrm{pH}$. This result is consistent with the conclusion reached by many researchers (Keever et al., 1989; Kumar et al., 2008; Hayat and Ali, 2004;Bai et al., 2010; Yan and Yan, 2013; Sharbazhery and Gareeb, 2016 ).

3- Plant fresh weight, foliage dry weight and roots fresh weight: Although there is no effect of 
adding Gel on the plant fresh weight, as shown in table(2), but it has significant effect on the verbena foliage dry weight, and dry weights ranged concentrations of 30,50 and $100 \mathrm{~g} / \mathrm{pot}$ discipline $39.2,41.7$ and $42.7 \mathrm{~g}$ respectively in comparison with the control that gave $31.4 \mathrm{~g}$. In another aspect it has added three Gel concentrations to reduce the weight of fresh roots significantly and reached for the three concentrations $30,27.9$ and $21.7 \mathrm{~g}$, respectively, compared to the Control $(42.2 \mathrm{~g})$.

The reason for increase in foliage dry weight was the result of adding Gel, which can absorb water up to 400 times its weight, they are being promoted as media amendments to enhance plant growth and increase media nutrient retention and shelf-life of pot crops, they can help with soil aeration and soil porosity (Bearce and McCollum, 1977; James and Richards, 1986; Ingram and Yeager, 1987; Keever et al., 1989; Hayat and Ali, 2004 ; Yan and Yan, 2013). This leads to an increase in foliage growth significantly compared to the roots groups, but the fresh weight of the plant (foliage + roots) has not increased significantly, but made a slight increase because when foliage weight is increased it reduces the weight of the roots at the same time. While the reason for reducing the roots fresh weight may return to the influence of absorbing high quantities of water, in addition to nutrients, and then slowly releasing the water through osmosis. When mixed into the soil, the Gel come in direct contact with the roots of plants, this is making the water easily available to plants. This translates to extremely efficient use of water in landscaping or with potted plants (Zohuriaan and Kabiri, 2008), and this leads to processing and provide for the needs of the roots and reduce the spread of the roots in the soil to long distances to search for these needs , as a result, it reduces the weight of roots mass of the plants .

4- Plant length, branches and floral clusters numbers : The results in the table ( 2 ) show that the increase in Gel levels from 30 to $100 \mathrm{~g} /$ pots has increased each of the qualities of the number of inflorescences, plant height, number of branches significantly, with the highest values of the recipe number of clusters and number of branches at the higher level of $100 \mathrm{~g}$ amounted to 77 raceme and 15 branch of the two treatments respectively, compared to the Control ( 26 and 30 branches ). While it does not increase significantly the effect of Gel levels from 30 to $100 \mathrm{~g}$, despite the superiority of the three concentrations compared to the Control significantly and that gave $55 \mathrm{~cm}$. The data in the table ( 2 ) indicated that plant length and maximum numbers of branches and floral clusters were observed in the treatment with $100 \mathrm{~g}$ Gel, the rate of increasing the plant length was reached to $140.9 \%$, the rate of increase in the branches and floral clusters number have reached $250-251.8 \%$ respectively .

5- Flowering period : The results in table 2 when increase the Gel to $100 \mathrm{gm}$ which reached 137 days compared to control (81 days), increasing percentage reached to $169.1 \%$, as well as each of the two treatments 75 and $30 \mathrm{~g}$ showed High a significant increased in flowering periods significantly increased flowering periods (122 and 97 days), But increasing percentage reached to 150.6 - $119.7 \%$ each respectively when compared with control .

The reason for this is because of the same reasons cited in the above paragraphs. Also was found by Kumar et al (2008) that hydrogel had a significant positive effects on growth and flowering of gerbera.

Depending on the results of the study conclude the following: We conclude that treatment of $100 \mathrm{~g}$ of gel added to the soil of potted in balcony's gardens under the environmental conditions of the Sulaymani city led to reduced irrigation requirements significantly by $20.3 \%$, and increase the soil moisture reached to $74.9 \%$, also increase each of the Plant length, branches and floral clusters numbers to $140.9-250-251.8 \%$, As well as also increase each of the Plant fresh, foliage fresh and foliage dry weight at high rates and are different for each of them, also increasing ratio of flowering period to $169.1 \%$. At the same time did not have an effect on soil $\mathrm{pH}$.

Based on the results and conclusions of the study, we recommend using Gel on allowable rates when planting flowers and plants in the gardens of balconies to their positive effect. 
Table (1): The effect of plant gel on same characteristics of soil.

\begin{tabular}{lcccc}
\hline & Treatments & irrigation water & Soil moisture & Soil $\mathrm{pH}$ \\
& requirements $(\mathrm{L})$ & $(\%)$ & & \\
\hline Control & $64 \mathrm{a}$ & $12.75 \mathrm{~b}$ & $7.36 \mathrm{a}$ \\
$30 \mathrm{gm}$ & $61 \mathrm{~b}$ & $20.60 \mathrm{a}$ & $7.30 \mathrm{a}$ \\
$75 \mathrm{gm}$ & $56 \mathrm{c}$ & $20.45 \mathrm{a}$ & $7.34 \mathrm{a}$ & \\
$100 \mathrm{gm}$ & $51 \mathrm{~d}$ & $22.30 \mathrm{a}$ & $7.38 \mathrm{a}$ & \\
\hline
\end{tabular}

Treatments with same letters are non-significant and treatment bearing different letters are significantly different at $5 \%$ level probability .

Table (2): Effect of plant gel on some characteristics Verbena canadiensis in balacony.

\begin{tabular}{llllllll}
\hline Floral & $\begin{array}{l}\text { Plant length } \\
\text { period(D) }\end{array}$ & $\begin{array}{l}\text { Plant fresh } \\
\text { clusters No. }\end{array}$ & $\begin{array}{c}\text { Roots fresh } \\
(\mathrm{cm})\end{array}$ & $\begin{array}{c}\text { Foliage dry } \\
\text { weight }(\mathrm{g})\end{array}$ & $\begin{array}{c}\text { Branches } \\
\text { weight }(\mathrm{g})\end{array}$ & weight $(\mathrm{g})$ & Numbers \\
\hline Control & $81 \mathrm{~d}$ & $20.0 \mathrm{c}$ & $55 \mathrm{~b}$ & $170.2 \mathrm{a}$ & $42.2 \mathrm{a}$ & $31.4 \mathrm{~b}$ & $26 \mathrm{c}$ \\
$30 \mathrm{gm}$ & $97 \mathrm{c}$ & $32.5 \mathrm{bc}$ & $70 . \mathrm{a}$ & $174.8 \mathrm{a}$ & $30.0 \mathrm{~b}$ & $39.2 \mathrm{a}$ & $30 \mathrm{ab}$ \\
$75 \mathrm{gm}$ & $122 \mathrm{~b}$ & $43.0 \mathrm{~b}$ & $72.5 \mathrm{a}$ & $178.2 \mathrm{a}$ & $27.9 \mathrm{~b}$ & $41.7 \mathrm{a}$ & $41 \mathrm{~b}$ \\
$100 \mathrm{gm}$ & $137 \mathrm{a}$ & $68.0 \mathrm{a}$ & $77.5 \mathrm{a}$ & $184.7 \mathrm{a}$ & $21.7 \mathrm{~b}$ & $42.7 \mathrm{a}$ & $65 \mathrm{a}$
\end{tabular}

Treatments with same letters are non-significant and treatment bearing different letters are significantly different at $5 \%$ level probability.

\section{REFERENCES}

- Bai, W.; H. Zhang; B. Liu; Y. Wu and J. Song( 2010)_Effects of super-absorbent polymers on the physical and chemical properties of soil following different wetting and drying cycles. J. Soil Use and Management, Vol 26, Issue 3 : 253260.

- BAKER SW.(1991) The effect of polyacrylamide copolymer on the performance of Lolium perenne L.turf grown a sand root zone. Journal of Sports Turf Research Institute $67: 66$ - 82.

- Bearce, B.C. and R.W. McCollum (1977) A comparison of peatlite and non composted hardwood-bark mixes for use in pot and bedding-plant production effects of a new hydrogel soil amendment on their performance. Flor. Rev. 161(4169):21-23, 66.

- Burrell, C. C.(1999) Perennial Combinations. St.Martins Press,London -UK.

- Bowman, D.C.; Richard Y.E. and J.L. Paul (1990) Fertilizer Salts Reduce Hydration of Polyacrylamide Gels and Affect Physical Properties of Gel-amended Container Media. Jor. of Amer. Soc. Hort. Sci. 115(3):382-386.

- EL HADY OA, TAYEL MY and LOFTY AA.(1981) Super gel as a soil conditioner. II. Its effects on plant growth, enzyme activity, water use efficiency and nutrient uptake. Acta Horticulturae 19 : 257 - 265.
- Flink, C.A. and R.M. Searns (1993) Aguide to Planning, Design and Development. Island press, Washington, D.C. USA.

- Sharbazhery, Ali O. and Berivan A. Gareeb(2016) Response of Turf Grass Mixture to Some Soil Amendment (Peat Moss, Perlite and Plant Gel) Under Sulaimani Governorate (Pishder Region) Conditions . Journal of Univ. of Duhok (JDU) Vol.19,No 1, 2016.

- Gehring, J.M. and A.J. Lewis (1980) Effect of hydrogel on wilting and moisture stress of bedding plants. J. Amer. Soc. Hort. Sci. 105:511-513.

- Hayat,R. and S. Ali (2004) Water Absorption by Synthetic Polymer (Aquasorb) and its Effect on Soil Properties and Tomato Yield. International Journal of Agriculture \& Biology. (6) 6 : 9981002.

- Ingram, D. L. and T. H. Yeager (1987) Effects of irrigation frequency and a water-absorbing polymer amendment on ligustrum growth and moisture retention by a container medium. J. Environ. Hort. 5:19-21.

- Jamalpour, H.; A.M. Torkashvand; s. Seadaghathoor and N. Negahdar (2013) Evaluation the effect of different medias, superabsorbent polymers and irrigation period on increasing water holding and delaying Permanent wilting point in (Lysimachianummularia cv. Aurea). Annals of Biological Research, (4) :29-31. 
- James, E.A. and D. Richards (1986) The influence of iron source on the water-holding properties of potting media amended with water absorbing polymers. Scient. Hort. 28:201-208.

- Jatav, G. K.; R. Mukhopadhyay and N. De.(2013) Charcterization of Swelling Behaviour of Nanoclay Composite. International Journal of Innovative Research in Science, Engineering and Technology Vol. 2, Issue 5, ISSN: 23198753.

- Johnson, M.S. (1984a) Effect of soluble salts on water absorption by gel-forming soil conditioners. J. Sci. Food Agr. 35:1063-1066.

- Keever, G.J., G.S. Cobb, J.C. Stephenson and W.J. Foster ( 1989) Effect of hydrophylic polymer amendment on growth of container grown landscape plants. J. Environ. Hort. 7:52-56.

- Kumar,S.; S. Anupama; S. Bhupinder and Sharma R. (2008) Influence of vermi-products and pusa hydrogel on growth and flowering of landscape gerbera under greenhouse condition. J. of Ecohydrology \& Hydrobioliogy. Vol. 8, 1 : 67 75.

- PILL WG and JACONO CC. (1984) Effects of hydrogel incorporation in peat-lite on tomato growth and water relations. Communications in Soil Science and Plant Analysis 15 : 799 - 810.

- Taylor, K.C. and R.G. Halfacre (1986) The effect of hydrophilic polymer on media water retention and nutrient availability to ligustrum lucidum HortScience 21:1159-1161.

- Wang, Y.T.; Gregg, L.L. (1990) Hydrophilic polymers - Their response to soil amendments and effect on properties of a soil less potting mix. J. Am. Soc. Hort. Sci. 115, 943-948.

- Yan, L. and Yan S. (2013) Effects of Super Absorbent Resin on Leaf Water Use Efficiency and Yield in Dry-land Wheat. Advance Journal of Food Science and Technology 5(6): 661-664, ISSN: 2042-4868; e-ISSN: 2042-4876.

- Zhang, J.; Chen, H.; Li, P.; Wang, A.( 2006) Study on superabsorbent composite, 14. Preparation of poly(acrylic acid)/organo-attapulgite composite hydrogels and swelling behaviors in aqueous electrolyte solution. Macromol. Mat. Eng. 291, 1529-1538.

- Zohuriaan, M. and K. Kabiri (2008) Superabsorbent Polymer Materials: A Review. Iranian Polymer Journal 17 (6) : 451-477.

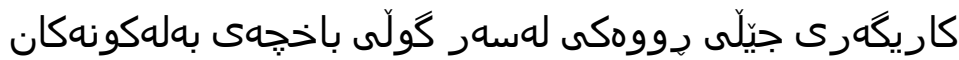

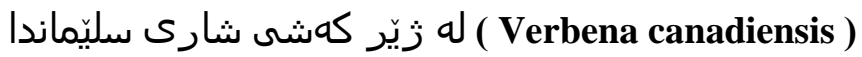

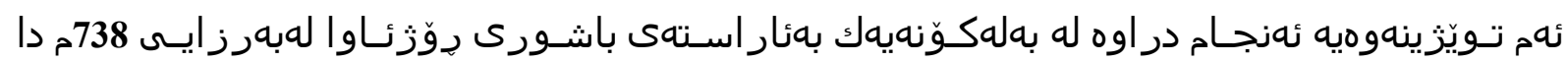

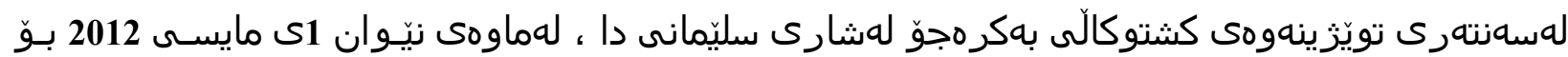

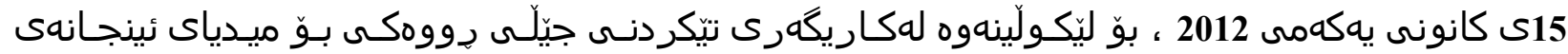

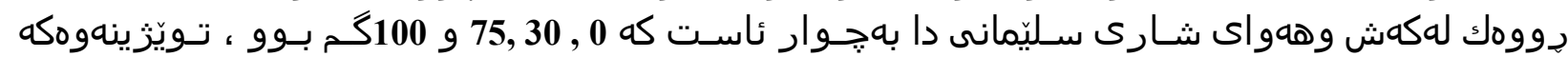

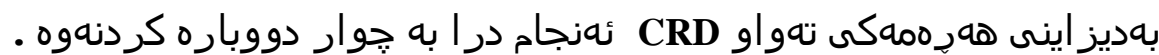

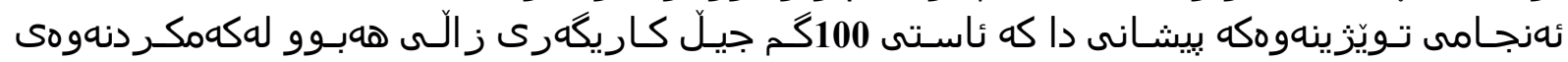

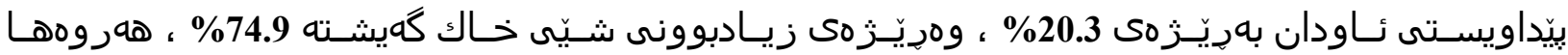

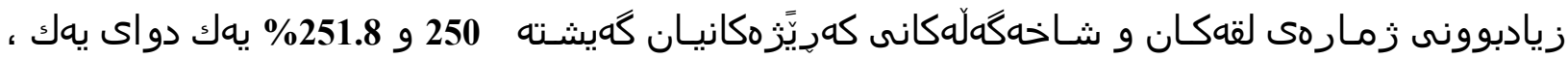

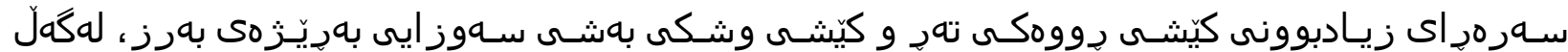

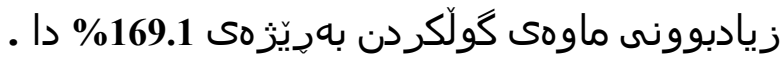

